\title{
ボルテックス・フラップ付きデルタ翼の静的ロール特性についで*1 Static Measurements of Rolling Delta Wings with Vortex Flaps
}

\author{
安部浩子*2 ・李家賢 一*3 ・ 砂田保 人*3 \\ Hiroko Abe, Kenichi Rinore and Yasuto SunAda
}

Key Words: Delta Wing, Vortex Flap, Rolling Motion

\begin{abstract}
Static normal force and rolling moment measurements for $60^{\circ}$ and $70^{\circ}$ delta wings with vortex flaps have been done for different roll angles at a Reynolds number based on a centerline chord of $1.3 \times 10^{5}$. Smoke visualization tests have also been done. Results show that the $60^{\circ}$ delta wing is statically unstable in roll at the angle of attack of $35^{\circ}$ when vortex flaps were deflected $30^{\circ}$ downward. This is because the chordwise position where the vortex breakdown occurs is different for the left and right wings when in roll. The $70^{\circ}$ delta wing with vortex flaps possesses static roll stability. Static rolling moment hysteresis has been observed for the $60^{\circ}$ delta wing with a flap deflection angle of $30^{\circ}$ at an angle of attack of $45^{\circ}$.
\end{abstract}

\section{1. 序論}

航空機の高速化に伴い, 大きな後退角を有する三角翼 （デル夕翼）またはそれに類似した翼を使用した航空機が 開発されてきた。これらの機体が大迎角を取ると,デル夕 翼の前縁から剥離した流れが翼面上で卷き込まれ，一対の 前縁剝離渦を形成する ${ }^{(\sim 4)}$ 。この前緑剝離渦のために, 翼 面に上向き垂直な力向に吸引力が誘起される（vortex lift).このためデル夕翼の空力特性は, 従来の翼に比べて 揚力傾斜が小さいこと，扔よび，その結果として最大揚力 を得る迎角が従来の翼に比べて大きいという特徵を有する ことになる。したがって離着陸等の低速飛行時にデル夕翼 機は大きな迎角を取る必要がでてくる。この低速, 大迎角 の状態でデルタ翼はしばしば wing rock と呼ばれる運動 を起こすことが知られている ${ }^{5-8)}$. wing rock は一定の振 幅と周波数を持つ自励的なロール振動である. 前縁剝離洞 の強さ，拉よびロール角変化に伴う渦位置の変化が wing rockに大きな影響を及活すものと考えられている．

また，vortex liftによって翼に働く抗力は多大なものと なる。このため空力特性の代表的な指標である揚抗比はデ ル夕翼の場合，一般に低い值となる。この低速に扔けるデ ル夕翼の空力特性を改善するために考案された前縁デバイ スの一つに vortex flap がある9,10). vortex flap とはデル 夕翼前縁に取り付けられた下方へ折り曲げることのできる フラップ0ことである. vortex flap は, フラップ上に生 ずる前縁剝離洞が生み出す吸引力を利用して, デル夕翼の 揚抗比の改善を実現している(第 1 図参照).

wing rock 現象が vortex flap の特性に及ぼす影響を調

*1 (C) 2001 日本航空宇”利学会

半成 12 年 $10 \mathrm{H} 2 \mathrm{H}$, 第 32 以流体力学講演会にて講演。州成 12 年 10 月 2411 原稿受理

*2 東京大学大学院

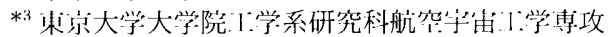

ベることは興味梁いことである。そこで本研究では，まず ボルテックス・フラップ付きデル夕翼が静的にロール角を 有している時（自由振動はさせないで, 模型のロール角が 固定されている時）の空力特性を明らかにすることを目的 として，実験を行った。そのために後退角が $60^{\circ}$ と $70^{\circ}$ の 鋭い前縁を有するボルテックス・フラップ付きデルタ翼模 型を用いて, ロール角を有している時の模型に働く空気力 (ローリングモーメント等)を測定した。更に，翼まわり の流れの様子を知るために煙を使った可視化も行った。な お，ボルテックス・フラップ付きデル夕翼の静的ロール特 性に関しては他の報告は見られないが, vortex flapでは なく左右非対称に折り曲げるフラップ付きデル夕翼につい ての静的ロール特性の報告は文献 11)にある。

\section{2. 実験装置および方法}

2.1 実験装置 実験に使用した風洞は三次元フラッタ 一風洞（東京大学丁学部，押し込み型低速風洞）である。 測定部は $0.6 \mathrm{~m} \times 0.6 \mathrm{~m}$ の開放型でモーター上流側の吸込 门直径は $1.4 \mathrm{~m}$ である.

実験に使用したデル夕翼模型の概略を第 2 四に示す。後 退角は $60^{\circ}$ と $70^{\circ}$, 最大翼弦長 cは $200 \mathrm{~mm}$, 翼の先端か ら後縁のセミスパン $75 \%$ 位置にかけてフラップのヒンジ 線が左右にある.フラップの折り曲げ角度 $\delta_{f}$ がそれぞれ $0^{\circ}$ と $30^{\circ}$ の四種類の模型を使用し, 箺験を行った. フラッ プ折り曲げ角度 $\delta_{f}$ はフラップヒンジ線に直交する面内で 定義した (下向きを正). 肉厚 $1 \mathrm{~mm}$ のアルミ板を使用 し, 前縁, 後縁とも鋭い前縁を有するように, 前縁と後縁 0)各辺に淔角方们 $5 \mathrm{~mm}$ 位置（図中 bevel line と表記）氻 ら各辺にかけてト下面ともに削ってある（上下面がな寸角 度は約 $11^{\circ}$ である)。模型を天科に固定する支柱は直径 10 $\mathrm{mm}$, 肉厚 $1 \mathrm{~mm}$ のジュラルミン製パイプを使用した。支 柱は翼上面側のみ半山状に翼弦位㯰 $x / c=0.75$ まで延び ている（ $x$ は翼頂点から翼弦加问にとった座標）。な押， 


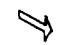

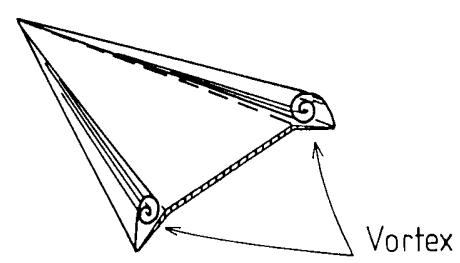

Flap

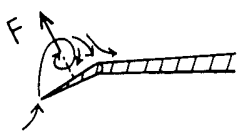

第 1 网 ボルテックス・フラップ付

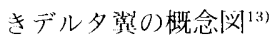

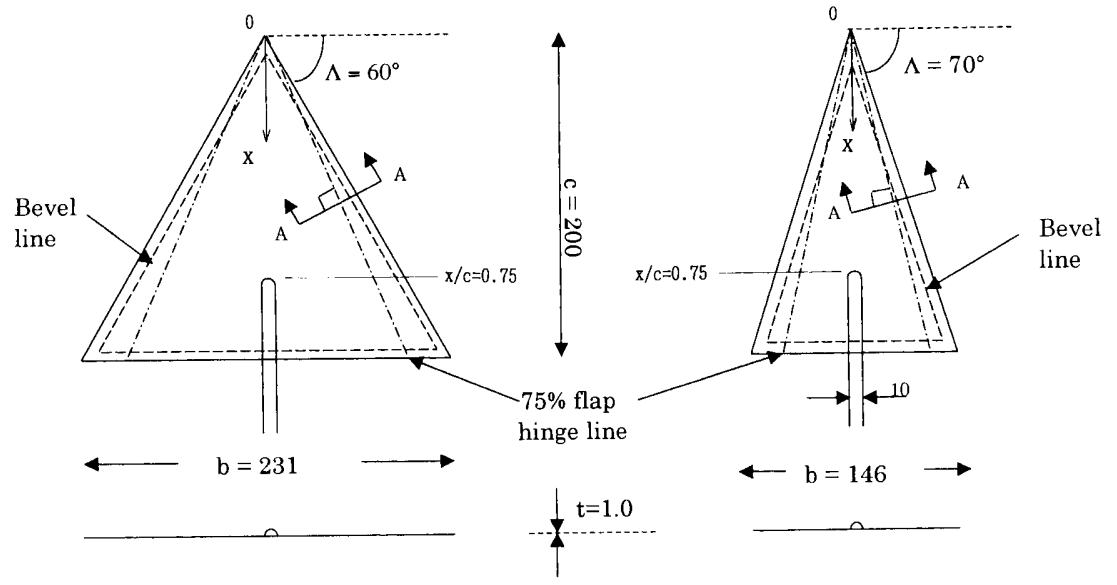

(unit $\mathrm{mm}$ )

Section A-A

第 2 闵 ボルラックス・フラッブ付きデルタ翼模型

筆者の一人が過去に行った実験(10,13) では， $\delta_{f}=30^{\circ}$ におい て後退角 $60^{\circ}, 70^{\circ}$ 共に vortex flap の効果が見られたた め, 本実験に打いても $\delta_{f}=30^{\circ}$ の場合について実験を行う こととした。

2.2 実験方法および計測装置 模型に働く法線力係数 $C_{N}$ とローリングモーメント係数 $C_{l}$ を計測した。風洞風 速は $U_{\infty}=10 \mathrm{~m} / \mathrm{s}$ に扔いて測定し, 最大翼弦長に基づくレ イノルズ数は $1.3 \times 10^{5}$ である.ロール角 $\phi$, ローリング モーメント係数 $C_{l}$ 等の定義図を第 3 図に示す。模型と天 科，ステッピングモーターが同軸になるように支持台に取 り付けられている。模型は支柱を介して, 文献 12)で使用 された天科に固定されており，模型と天科全体をステッピ ングモーターで機体軸まわりに回転させることができる。 測定される力は回転する模型表佰に対して常に法線方向の 成分 $N$ であり，モーメントは模型の中心軸に対するロー ル方向成分 $M$ である。

模型の迎角は支持台によって $\alpha=0^{\circ}$ から $45^{\circ}$ まで連続的 に変えられる。模型のロール角は, 右翼が下がるように口 一ルする方向を正として $\phi=-30^{\circ}$ から $30^{\circ}$ まで模型後方 から見て時計周りに $2^{\circ}$ 抢きに測定し，その後 $30^{\circ}$ から 一 $30^{\circ}$ まで反時計周りに $2^{\circ}$ 抢きに測定した。この測定を, 最低 3 测繰り返し, それらの平均を取った。一様流流速 $U_{\infty}$ を $0 \mathrm{~m} / \mathrm{s}$ にして（風洞を停止して）測定した值を，一 様流流速 $U_{\infty}=10 \mathrm{~m} / \mathrm{s}$ で測定した值から差し引くことによ り，模型などに働く慣性力を削除し，空気力を得た。

な扔風洞境界の影響, blockage 補正等の修正は行って いない. 空力係数の無次元化に関しては, フラップ角 $\delta_{f}$ $=0^{\circ}$ のときの翼面積を $\delta_{f}=30^{\circ}$ 模型に対しても用いて空力 係数を求めた。

前縁剩離洞の状態変化を調べるために, 煙を使った流れ の可視化を行った。ある $x / c$ 位㯰において, 翼の左右か ら翼弦線に直交した方向の平面内をシート状の光で照ら し,この断面での前縁剩離渦の様子を翼後力に配置したデ

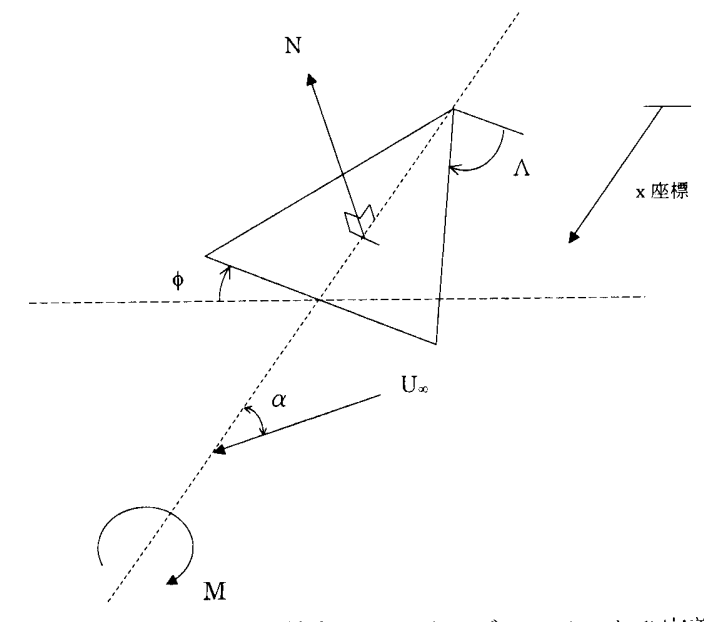

第3咸ロール们, 法線力, ローリングモーメントの惩䉝

ジタルビデオカメラで撮影した。このとき，翼弦位置の違 いに上る前縁剝離珮の状態変化を調べるため, 二つの翼弦 位置 $(x / c=0.33,0.66)$ に扔いて観測を行った。

可視化時の一様流速度は煙の密度を高めるため原則とし て $U_{\infty}=6 \mathrm{~m} / \mathrm{s}$ としたが, 後述するロール不安定やヒステ リシスが発生している迎角では, 力測定結果との, 上り良 い比較を行うため $U_{\infty}=10 \mathrm{~m} / \mathrm{s}$ とした。な押, 通常は煙発 生パイプを翼のすぐ上流側に設置して可視化を行ったが, ロール不安定や七ステリシスが発生する形態では, 桯発生 パイプが流れ場に極力影響を及ぼさなように，風润ノズ ル上流部から煙を流入させた。

\section{3. 実験結果と考察}

3.1 ロール角 $0^{\circ}$ の場合 法線力係数 $C_{N}$ について今 回測定した後退角 $70^{\circ}$, フラップ角 $\delta_{f}=0^{\circ}, 30^{\circ}$ の実験結果 と文献 13) 0実験結果（フラップ角 $\delta_{f}=30^{\circ}$ ) を比較した 図第 4 四に示す。文献 13) に用いられた翼の平面形やフ ラップ平面形状は，今回の模型と相似である。ただし翼断 
面形は晎なる。また最大翼弦長に基ー゙くレイノルズ数は 1 $\times 10^{6}$ であり今回の実験に比べて一桁大きい、第 4 四によ ると迎角 $20^{\circ}$ 付近まで $\delta_{f}=30^{\circ}$ の結果は闭者で非常に良好 な一致を示している.文献 13)でも指摘されているよう に, 鋭い前縁を有したデル夕翼の空力特性は, 翼断面形状 やレイノルズ数にあまり依存しないことがこの図からもわ かる。なお迎角 $20^{\circ}$ 以上では今回の実験と文献 13)の間で その失速特性などに違いが見られるが，これは風洞の違い による渦の breakdown 位置の変化等のためである。

3.2 静的ロール特性 第 5 図と第 6 図にロール角を有 するとき0静的空気力測定結果を示す。第 5 図には縦軸に 法線力係数 $C_{N}$, 横軸にロール角 $\phi$ を, 第 6 四には縦軸に ローリングモーメント係数 $C_{l}$, 横軸にロール角 $\phi を と$ り，それぞれ迎角 $\alpha$ をパラメータにとっている．各図共 に図 a）に $\Lambda=60^{\circ}, \delta_{f}=0^{\circ}$, 四 b) $に \Lambda=70^{\circ}, \delta_{f}=0^{\circ}$, 図 c) に $\Lambda=60^{\circ}, \delta_{f}=30^{\circ}$, 図 d) $\Lambda=70^{\circ}, \delta_{f}=30^{\circ}$ に おりる結果を示す。

第 5 図a）は後退角 $60^{\circ}$, フラップ折り曲げ角 $\delta_{f}=0^{\circ}$ に 抢ける $C_{N}$ 中曲線である。迎角 $\alpha$ が $35^{\circ}$ 以下ではロール角 の絶対値 $|\phi|$ を増加させると法線力係数 $C_{N}$ は単調に減少 している。しかし， $\alpha=40^{\circ}$ ではロールするにつれて法線 力係数 $C_{N}$ は徐々に増大している.

第 5 図b)に後退角 $70^{\circ}$, フラップ折り曲げ角 $\delta_{f}=0^{\circ}$ に おける測玍結果を示す. $\alpha<40^{\circ}$ ではロール角の絶対值 $|\phi|$ を増加させると法線力係数 $C_{N}$ は単調に減少している。 ールによって $C_{N}$ が減少する原因として，デル夕翼上面側 の流れの変化だけではなく, 下面側の受ける空気力変化の 影響も考えられる， $\alpha \geq 40^{\circ}$ に扔いて， $\phi=0^{\circ}$ からロールし 始めると法線力係数 $C_{N}$ は増加していくが, 更にロールす ると逆に $C_{N}$ は減少し始めている。な招, 図a), b)共に $\alpha=40^{\circ}$ と $45^{\circ}$ では $C_{N}$ の分布形状が大きく変化している. これは, 翼面上での前縁剥離渦の breakdown 発生の兼ね 合いによって生じたのではないかと考えられる。第 5 図の 変化の傾向は文献 12)で報告された後退角 $76^{\circ}$ デルタ翼の $C_{N}-\phi$ 分布とほほ同様である。

第 5 図 c) に後退角 $60^{\circ}$, フラップ折り曲げ角 $\delta_{f}=30^{\circ}$ に 抢ける測定結果を示す. $\alpha \leq 40^{\circ}$ ではロール角の絶対值 $|\phi|$ を増加させると法線力係数 $C_{N}$ は単調に減少している。 $\alpha$

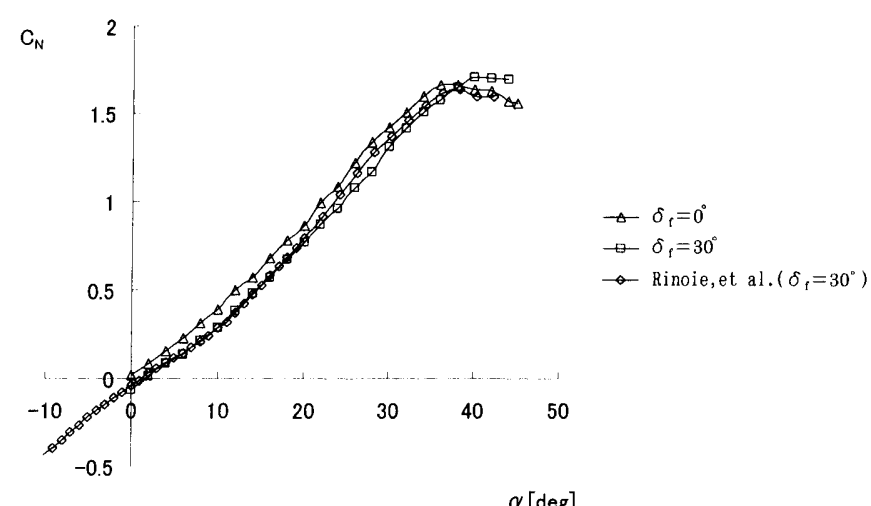

第 4 図 ロール角 $0^{\circ}$ の場令の $C_{N}-\alpha$ 分布 $=45^{\circ}$ では $|\phi|$ を増加させても最初 $C_{N}$ はほぼ一定の傎を 示すが, $\phi=-16^{\circ} \sim-24^{\circ}$ と $18^{\circ} \sim 28^{\circ}$ の範进で $C_{N}$ が急激 に増加し, またロールさせる方向の違いにより, 異なる $C_{N}$ の值を示し，いわゆるヒステリシスを生じている。な 押，測定にあたっては迎角一定の状態でロール角 $0^{\circ}$ から $2^{\circ}$ 拉きに正の方向にロール角を変化させながら行い, か つ各測定ロール角において充分時間が経過した後に空気力 の計測を行っている。またロール角が $30^{\circ}$ に達したところ で今度は負の力向に模型をロールさせてゆき, 同様な計測 を行っている．上ステリシスは,この形態 $\left(\alpha=45^{\circ}\right)$ にお いてのみ見られた。これについては 3.4 節において詳しく 検討する。

第 5 図 d) に後退角 $70^{\circ}$, フラップ折り曲げ角 $\delta_{f}=30^{\circ}$ に

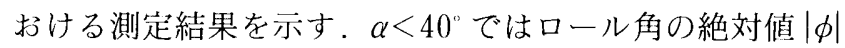
を増加させると法線力係数 $C_{N}$ は単調に減少している. $\alpha$ $=45^{\circ}$ では, 第 5 図 b) と同様に $C_{N}$ はほぼ一定の值を示し て抢り, $|\phi|=25^{\circ}$ から $|\phi|$ を増加させると $C_{N}$ は減少して いる。

次にローリングモーメント $C_{l}$ の測定結果を第 6 図に示

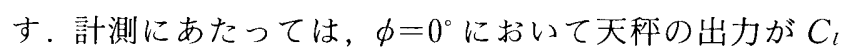
$=0$ となるように調整した後に, 模型のロール角を変化さ せている，ロール角 $\phi$ が正でローリングモーメント $C_{l}$ が 負であるとき, あるいは $\phi$ が負で $C_{l}$ が正であるときに は, デル夕翼にロール角を減少させる復元ローリングモー メントが働くことになり，この場合デル夕翼は，いわゆる ロール安定の状態になっている. 第 6 図 a) $\left(\Lambda=60^{\circ}, \delta_{f}=\right.$ $\left.0^{\circ}\right)$ によると $\alpha=25^{\circ}, 30^{\circ}$ を除いてローリングモーメント係 数 $C_{l}$ のロール角に対する勾配は, 同じ $\alpha$ では $\phi$ が変化し てもほぼ一定で負の傾きを示しており，ロール角変化に対 する復元モーメントが翼に働いていることがわかる．これ に対して $\alpha=30^{\circ}$ では $\phi=-12^{\circ} \sim 16^{\circ}$ の間でこの勾配は正 負逆転し $C_{l}$ の符号も逆転しており, ロ一ル不安定になっ ていることがわかる。

第 6 図 b) $\left(\Lambda=70^{\circ}, \delta_{f}=0^{\circ}\right)$ によると $\alpha \leq 30^{\circ}$ ではローリ ングモーメント係数の傾きは $\phi$ が変化しても同じ $\alpha$ では ほぼ一定でありロール安定になっている.一方 $\alpha \geq 35^{\circ} て ゙$ はローリングモーメント係数の傾きの正負が逆転するとこ ろが存在する。ただし, 第 6 図a）の場合と異なり，ロー ル不安定が起こるような $C_{l}$ の符号の逆転は見られない.

第 6 図 c) $\left(\Lambda=60^{\circ}, \delta_{f}=30^{\circ}\right)$ ではローリングモーメント 係数の傾きは $\alpha=30^{\circ}, 35^{\circ}, 45^{\circ}$ を除き $\phi$ が変化しても同じ $\alpha$ ではほぼ一定である． $\alpha=35^{\circ}$ では $|\phi|$ が増加すると $\phi=$ 土4゙に扔いてロール安定から不安定へ,さらに $|\phi|$ を増加 させると $\phi= \pm 16^{\circ}$ においてロール安定へと移行している. $\alpha=45^{\circ}$ では $\phi=-16^{\circ} \sim-24^{\circ}, 18^{\circ} \sim 28^{\circ}$ の範囲でロール角 增大時と減少時共に, $C_{N}$ の場合と同様に（第 5 図 c)）七 ステリシスを生じている.

第 6 図 d) $\left(\Lambda=70^{\circ}, \delta_{f}=30^{\circ}\right)$ は全般的傾向は $\Lambda=70^{\circ}, \delta_{f}$ $=0^{\circ} \quad($ 第 6 図 b $) ）$ とほぼ同様である.

以上の力測定の結果を整理すると以下のようになる. 後 退角 $60^{\circ}, 70^{\circ}$ の場合共にボルテックス・フラップの有り無 


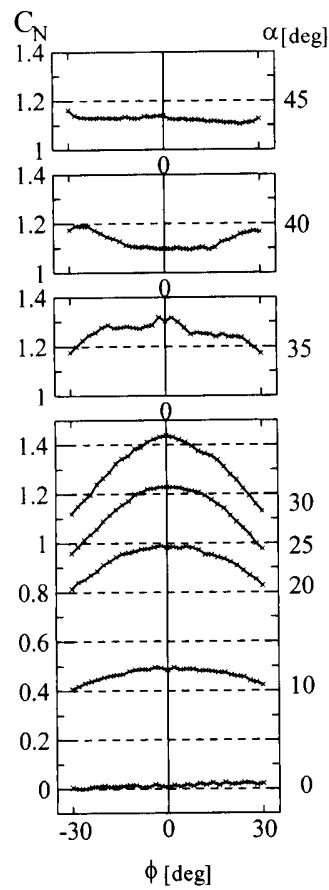

(a) $\Lambda=60^{\circ}, \delta_{\mathrm{f}}=0^{\circ}$

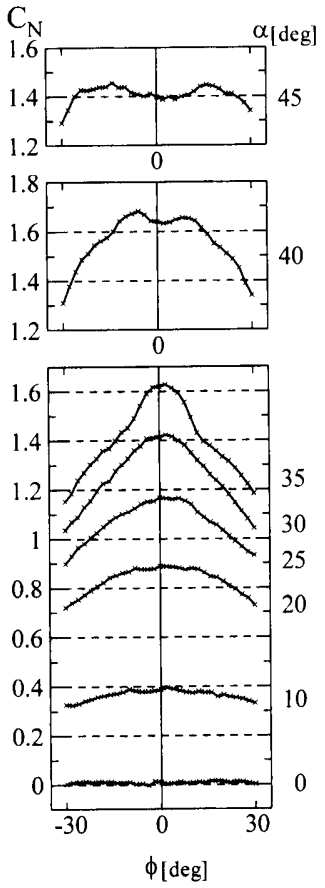

(b) $\Lambda=70^{\circ}, \delta_{\mathrm{f}}=0^{\circ}$
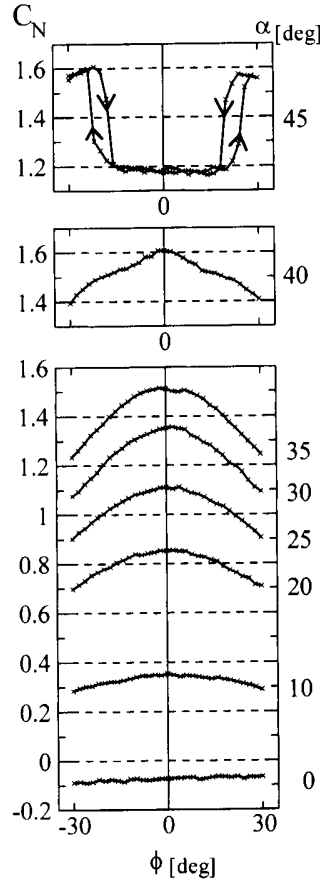

(c) $\Lambda=60^{\circ}, \delta_{\mathrm{f}}=30^{\circ}$

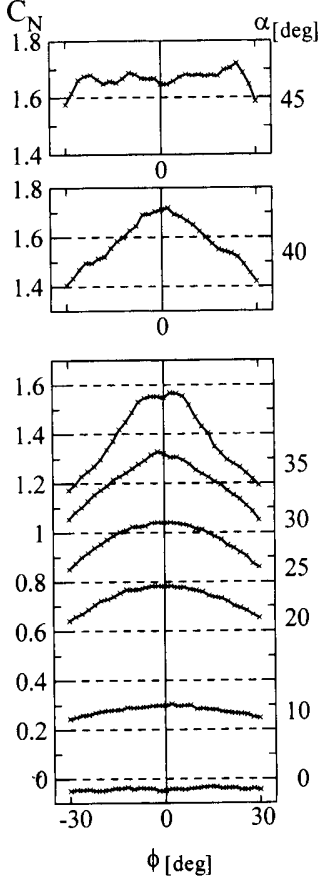

(d) $\Lambda=70^{\circ}, \delta_{\mathrm{f}}=30^{\circ}$

第 5 㲸 $C_{N}-\phi$ 曲線 $(\alpha-$ 定 $)$

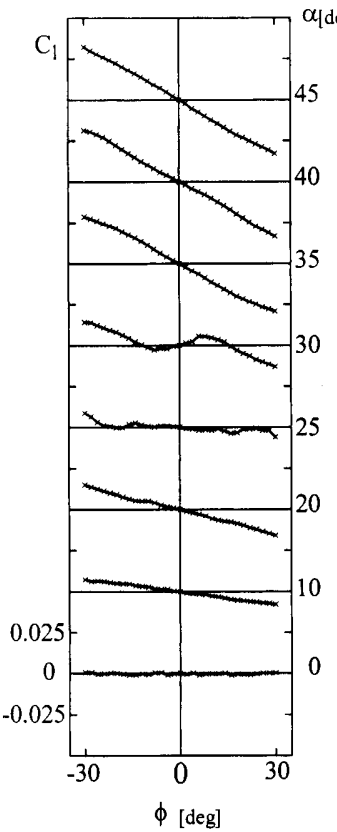

(a) $\Lambda=60^{\circ}, \delta_{\mathrm{f}}=0^{\circ}$

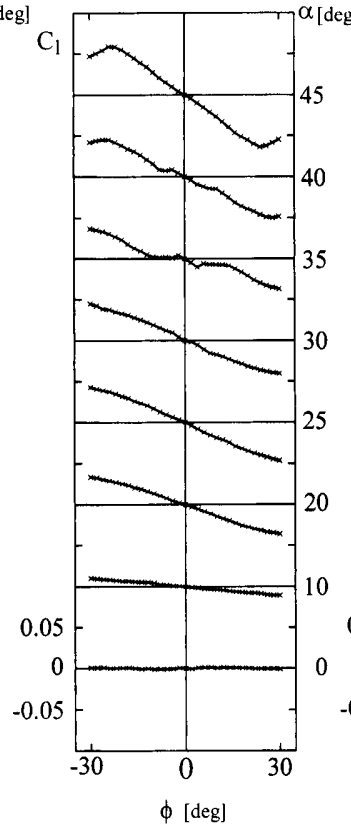

(b) $\Lambda=70^{\circ}, \delta_{\mathrm{f}}=0^{\circ}$

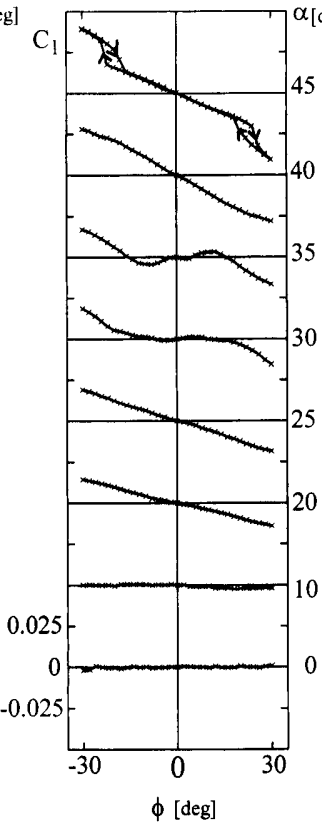

(c) $\Lambda=60^{\circ}, \delta_{\mathrm{f}}=30^{\circ}$

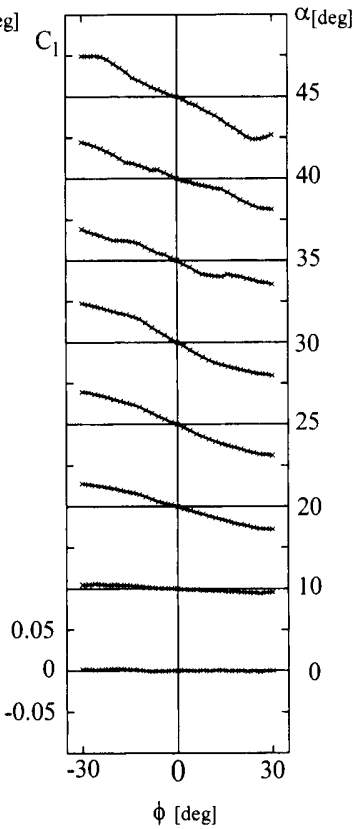

(d) $\Lambda=70^{\circ}, \delta_{\mathrm{f}}=30^{\circ}$

第 6 四 $C_{t^{-}}-\phi$ 曲線 $(\alpha$ 一定 $)$

しに関わらず，ほとんどの場合ロール角変化に対してロー ル安定である。ただし, 後退角 $60^{\circ}$ では $\delta_{f}=0^{\circ}, 30^{\circ}$ 共に特 定の迎角でロール不安定が観察された。なお他の文献によ ると静的ロール不安定は後退角 $65^{\circ} テ ゙ ル 夕$ 翼（胴体付模 型) ${ }^{14)}$ と後退角 $45^{\circ}$ デル夕翼 (丸い前縁) ${ }^{15,16)}$ で観測されて いるが, 後退角約 $70^{\circ}$ 以上のデル夕翼（後退角 $69^{\circ}$ 17), 後 退解 $76^{\circ}, 83^{\circ}{ }^{12,18)}$ ) では観測されていない。また今[回, 後 退角 $60^{\circ}, \delta_{f}=30^{\circ}, \alpha=45^{\circ}$ に拈いてのみ $C_{N}, C_{l}$ 共に $\phi$ 変化
に対するヒステリシスが観察された。このヒステリシス以 外に vortex flapの有り無しで明確な空気力の違いは特に は見られなかった。な拉，文献 13）でも報告されているよ うに, vortex flapはフラップ無しの場合に比べて, 迎角 を見かけ上小さくする特性がある（第 4 図参照）。このた め $60^{\circ}$ デルタ翼ではロール不安定が観測される迎角が $\delta_{f}$ $=0^{\circ}$ では $\alpha=30^{\circ}, \delta_{f}=30^{\circ}$ では $\alpha=35^{\circ}$ と, $\delta_{f}=30^{\circ}$ の場合 の方が大きな迎角になっている。 
3.3 流れの可視化 迎角を固定してロール角を変化さ せたときの翼弦長 $33 \%$ と6\%位置における断面の流れを 可視化した結果を第 7 図に示す。第 7 図a）は後退角 $60^{\circ}$, $\delta_{f}=0^{\circ}, \alpha=30^{\circ}$, 図 b) は後退角 $70^{\circ}, \delta_{f}=0^{\circ}, \alpha=35^{\circ}$, 図 c) は後退角 $60^{\circ}, \delta_{f}=30^{\circ}, \alpha=35^{\circ}$, 図 d) は後退角 $70^{\circ}, \delta_{f}=$ $30^{\circ}, \alpha=35^{\circ}$ に打ける結果である。四 a), c) の $\Lambda=60^{\circ}$ 翼で は第 6 図に示したようにロール不安定が見られたため, 力 測定と同じ計測条件になるように風速 $10 \mathrm{~m} / \mathrm{s}$ で撮影し た。な打 2.2 節で述べたように，残りのケースでは風速 6 $\mathrm{m} / \mathrm{s}$ で可視化を行った。第 4 眓でも議論したように鋭い 前縁を有するデル夕翼まわりの流れは、レイノルズ数（風 速）の変化に余り影響されない。そこで本実験では，煙の 密度を高め，より良好な可視化結果が得られるように力測 定の時よりも遅い風速 $(6 \mathrm{~m} / \mathrm{s})$ を用いた。ただしロール不 安定が観察された形態（第 6 図 a)，c））の上うにわず かな試験条件の違いが可視化結果に影響を及ぼす恐れがあ

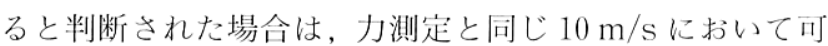
視化を行うこととした

後退角 $70^{\circ}$ の結果（第7眓b）, d) ) は $60^{\circ}$ の結果（四 a), c)）に比べてボルテックス・フラップ折り曲げ有り 無し共に, breakdownしていないときは非常にはっきり と渦の中心が見られ, 剝離渦の強度が強いことがわかる。
なお上述のように,この $70^{\circ}$ の結果は $60^{\circ}$ の結果（図a）, c)）と異なり風速 $6 \mathrm{~m} / \mathrm{s}$ で撮影されている。ただし風速 $10 \mathrm{~m} / \mathrm{s}$ においても確認のための可視化を行った。 $10 \mathrm{~m} / \mathrm{s}$

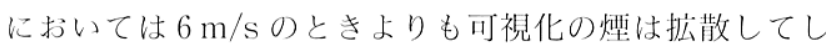
まっているが，70デル夕翼において剥離渦の中心は，6 $\mathrm{m} / \mathrm{s}$ のとと同様にはっきりと観察された.

第 7 図d）によると, ロールしていない状態からロール 角を変化させていくと，風下側（左翼）の前縁剥離渦の中 心は次第に模型中心から遠ざかって翼面から離れていき, 一方，風上側の翼上の前縁剝離渦に関しては，その断面積 が拡大していくことがわかる. $x / c=0.33$ 断面位置では $\phi=0^{\circ}$ において左右翼共に明確な焵の core が見えている が，ロールすると風上側（右翼）で洞の coreが見られな くなっている。逆に $x / c=0.66$ 断面位置では, ロールし た方 $\left(\phi=20^{\circ}\right)$ がロールしていない場合 $\left(\phi=0^{\circ}\right)$ に比べて 風下側（左翼）で渦の coreがはっきりと見えている。す なわち, 風上側 (右港) ではロール角の絶対值 $|\phi|$ が増加 するほど breakdownの発生位置は翼頂点に向かって前進 し, 逆に風下側（左翼）の洞ではbreakdownの発生位置 が後退する傾向があることが確認できる。この傾向はロー ル不安定が観測された第 7 図a），c）においても同様に見 られる。以上の説明はロールによる有効後退角の変化によ (a) $\quad \Lambda=60^{\circ}, \quad \delta_{f}=0, \quad \alpha=30$

$\mathrm{x} / \mathrm{c}=0.33$

$\mathrm{x} / \mathrm{c}=0.66$

(b) $\Lambda=70^{\circ}, \quad \delta_{f}=00^{\circ}, \quad \alpha=35$

$\mathrm{x} / \mathrm{c}=0.33$

$\mathrm{x} / \mathrm{c}=0.66$
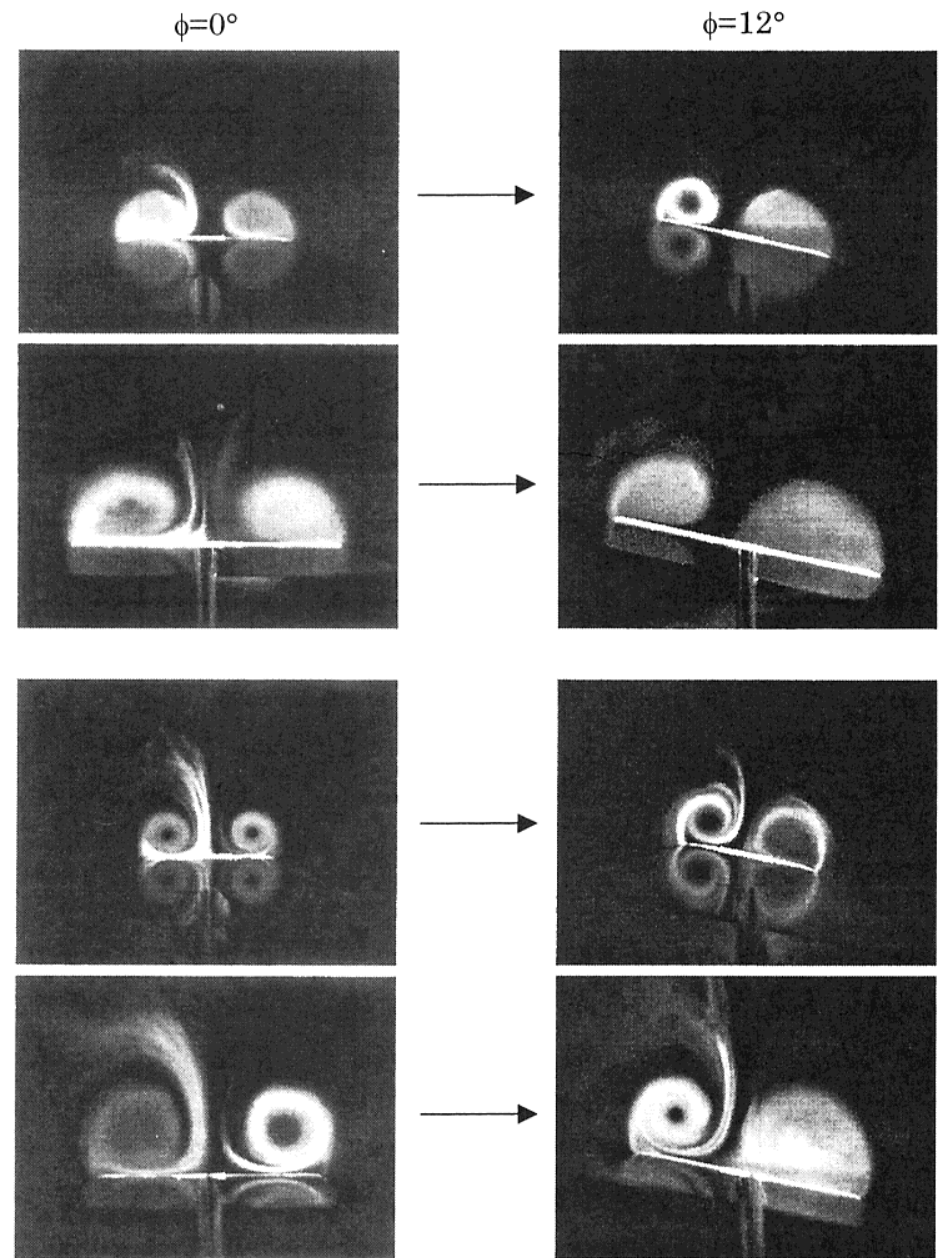

第 7 四 流机の川視化写真

$(296$ ) 
つても説明することができる。風上側（右翼）ではロール によってデル夕翼の有効後退角が減少し，風下側では増大 する7)。後退角が増大すると一般にデル夕翼上の渦は breakdownの発生位置が後退する。この変化の傾向は上 述の観察と一致する。すなわちロールに伴い，風下側では 有効後退角の増大により breakdown 位置は後方へ移動す るとともに，強くて小さい㟠が翼面近くにでき，渦による 翼への垂直力が強くなると考えられる．一方風上側では前 縁剥離渦の breakdown 発生位置は翼前方へと移動してい くため, 翼に対する渦の強度が弱くなり，渦による翼への 垂直力が弱くなる。これによって, 風下側を更に上に上げ ようとする法線力が風上側の法線力に勝り, ロール不安定 が起こる場合があるのではないかと考えられる。ただし， ロール角が更に増大寸ると，風下側の渦の breakdown 位 置が翼後縁よりも後方に位置するようになるために, 渦に よる翼への上向き法線力の増加率は少なくなる，一方風上 側の渦の断面積は拡大しているので, 渦が翼に影響を及ぼ す面積が増え, breakdownしてはいるものの渦全体によ る翼への垂直力は増していく。この結果, 風上側の法線力 が風下側の法線力に勝り, ロール角を減少させる方向にロ ーリングモーメントが働くため, 再びロール安定になると 考えられる。 なお, 以上考察したことは, 文献 19)の後退
角 $65^{\circ}$ 胴体付平板デル夕翼に関する考察とほぼ同様である

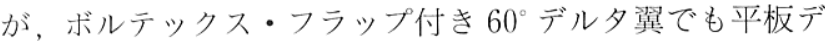
ル夕翼と同じような機構でロール不安定を生じていること がわかる。

第 8 図に $\Lambda=60^{\circ}, \delta_{f}=0^{\circ}$ に扔いて縦軸にローリングモー メント係数 $C_{l}$, 横軸に迎角 $\alpha$ をとり, ロール角をパラメ ータとして第 6 図のデータを用いて整理し直した図を示 す。図によるとローリングモーメント係数 $C_{l}$ が迎角 $20^{\circ} \sim 30^{\circ}$ 付近で急激に変化している. ロール角を一定にし て迎角を変化させていくと， $C_{l}$ の絶対值が小さくなる状 態があることがわかる. $\Lambda=60^{\circ}, \delta_{f}=0^{\circ}$ においてロール不 安定が観測されたのは $\alpha=30^{\circ}, \phi=10^{\circ}$ 付近の場合のみであ り，第 8 図でもこのとき $C_{l}$ は正負が逆転している。他の $\phi$ の值においても, 特定の $\alpha$ と $\phi$ の組み合わせのときに $C_{l}$ の值が負ではあるものの, その絶対值は小さくロール 不安定に近づいている場合があることが第 8 図より読みと れる。例えば $\phi=20^{\circ}$ のときは, $\alpha=25^{\circ}$ 付近でローリング

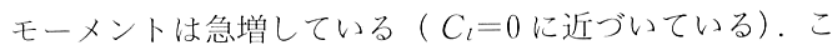
の $\phi=20^{\circ}$ の場合は $\phi=10^{\circ}$ のときに比べて迎角が小さいと きのローリングモーメントの絶対值自体が大きいのでロー ル不安定にまでは至らなかったとも解釈できる. なお, 後 退角 $70^{\circ}$ でロール不安定が見られなかったのは, 剥離渦の (c) $\Lambda=60, \quad \delta_{f}=30, \quad \alpha=35$

$\mathrm{x} / \mathrm{c}=0.33$

$\mathrm{x} / \mathrm{c}=0.66$

d) $\Lambda=70^{\circ}, \quad \hat{o}_{f}=30^{\circ}, \quad \alpha=35$

$\mathrm{x} / \mathrm{c}=0.33$

$\mathrm{x} / \mathrm{c}=0.66$

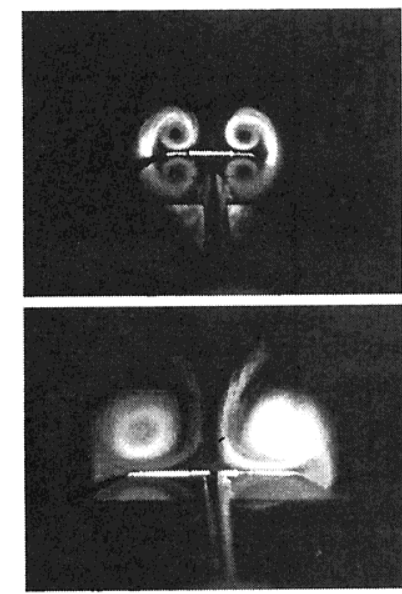

第 7 図 流れの可視化写真（続き）
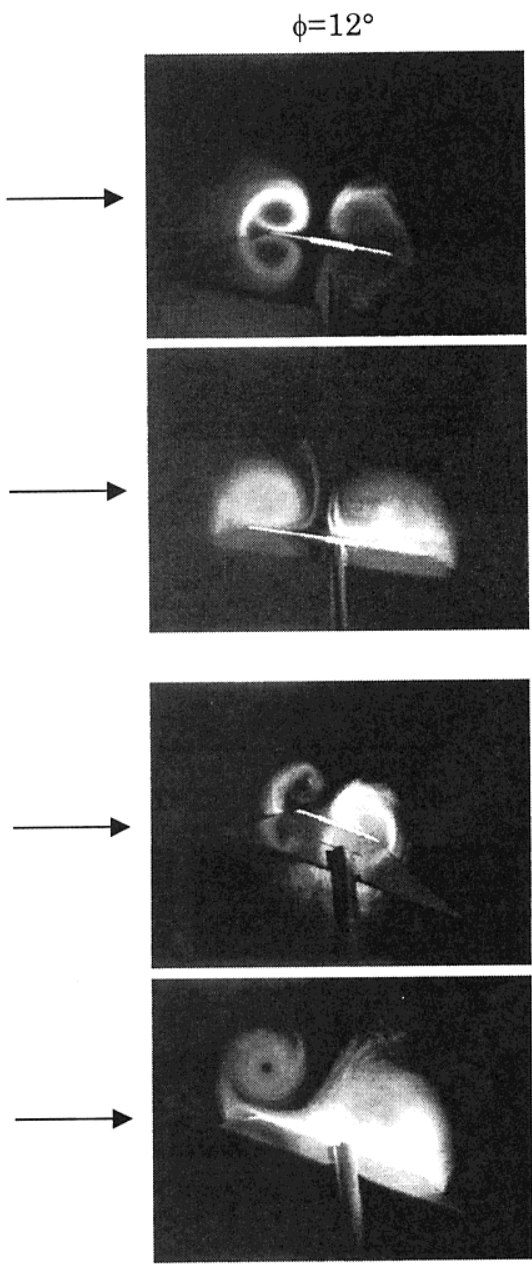

(297) 
力が後退角 $60^{\circ}$ に比べて全般にかなり強いこと(第 7 図 b)，d）参照）が影響を及ぼしていると考えられる。

3.4 後退角 $60^{\circ}$ ，フラップ折り曲げ角 $30^{\circ}$ におけるヒス テリシス 第 5 図 c), 第 6 図c)で見たように後退角 $60^{\circ}$, フラップ折り曲げ角 $30^{\circ}$ に扔いて $\alpha=45^{\circ}$ では $C_{N}, C_{l}$ 共にヒステリシスが観測された。そこでこの形態でのロー ル角 $\phi=18^{\circ}, 22^{\circ}, 26^{\circ}, 30^{\circ}$ に打ける 2 つの断面内 $(x / c=$ $0.33,0.66)$ の流れの可視化を行った結果を， $C_{l^{-}}-\phi$ 曲線と 重㸚合わせて第 9 図に示す。ヒステリシスが観察されない 最大の $\phi$ に求いて $\left(\phi=18^{\circ}\right), \phi$ を正方向に変化させたと き（これを「行き」と呼ぶ）の可視化写真を見ると（第 9 図中の写真 $\mathrm{a})), x / c=0.33,0.66$ 共に左翼側, 右翼側に それぞれほぼ同じ大きさの剝離渦を生じている，左右の渦 の配置は $\phi=22^{\circ}$ (「行き」写真b)）においてもほほ同じ であるが， $\phi=26^{\circ}$ (「行き」写真 c)）において風上側（右 翼）の渦が突然風下側（左翼）の渦の下に入り込んでい

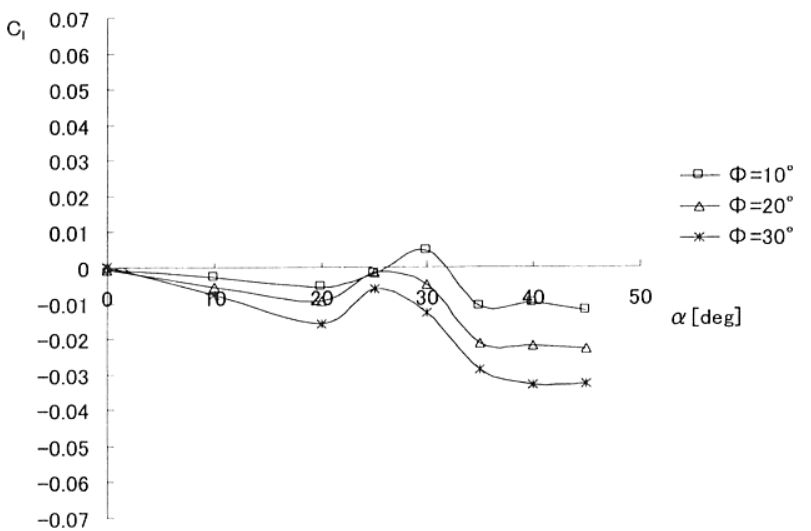

第 8 図 $C_{l^{-}}-\alpha$ 曲線 $\left(\phi\right.$ 一定, $\left.\Lambda=60^{\circ}, \delta_{f}=0^{\circ}\right)$
き，風上側の渦が翼面に近づいていることがわかる，さら に $\phi$ を増やしてゆき， $\phi=30^{\circ}$ (写真 d) ) からロール角を 滅らしていくと(これを「もどり」と呼ぶ)， $\phi=22^{\circ}$ まで 右翼上の渦が左翼上の渦の下にもぐり込む傾向が引き続い て見られ $\left(\phi=26^{\circ}, 22^{\circ}\right.$ ，写真 e), f) ), $\phi=18^{\circ}$ (写真 $\left.\left.\mathrm{g}\right)\right)$ に扔いてようやく最初の状態 (写真a) ) と同じ配置へと 変化し始めている。(な抢「もどり」の $\phi=18^{\circ}$ では両方 のタイプの渦配置が $x / c=0.66$ において非定常的に観察 された (写真 g) 参照). $\phi=16^{\circ}$ から $\phi$ を減少させていく と, 左右翼共にほぼ同じ大きさの剥離渦が存在する状態を 保ったままだった。

ここで渦の配置が翼模型に働く空気力に及ぼす影響につ いて考える。上述のように「行き」の $\phi=26^{\circ}$ に扔いて， 風上側（右翼）の渦が風下側（左翼）の渦の下に入り込む ようになった。このため風上側の渦が翼面に与える影響が 増大し, 翼面を持ち上げる方向に働く法線力が増すので, $\phi=26^{\circ}$ において急に復元モーメントが大きくなった $\left(C_{l}<\right.$ $0,\left|C_{l}\right|$ が増大) と考えられる。これと同じ理由により, $C_{\iota^{-}} \phi$ 曲線上で「行き」0 $\phi=26^{\circ} \sim 30^{\circ}$, および「もどり」 の $\phi=30^{\circ} \sim 18^{\circ}$ の範囲に関しても, 「行き」の $\phi=18^{\circ} \sim 26^{\circ}$ に比べて大きな復元モーメントが翼に衝いて,$C_{l^{-}} \phi$ 曲線 にヒステリシスを生じたと説明できる。 vortex flapを折 り曲げると, 風洞主流方向に対してフラップがな寸角度 は，フラップを折り曲げない場合に比べてかなり小さくな る。またロールしていると，この主流とフラップがな寸角 度は左右の翼で異なってくる。ロール角が大きくなるにつ れて，この左右のフラップ面と風洞主流がな寸角度が大き く異なってくることが, 左右の渦配置に違いを生じ，ひい てはヒステリシスの発生に関係しているのではないかと考

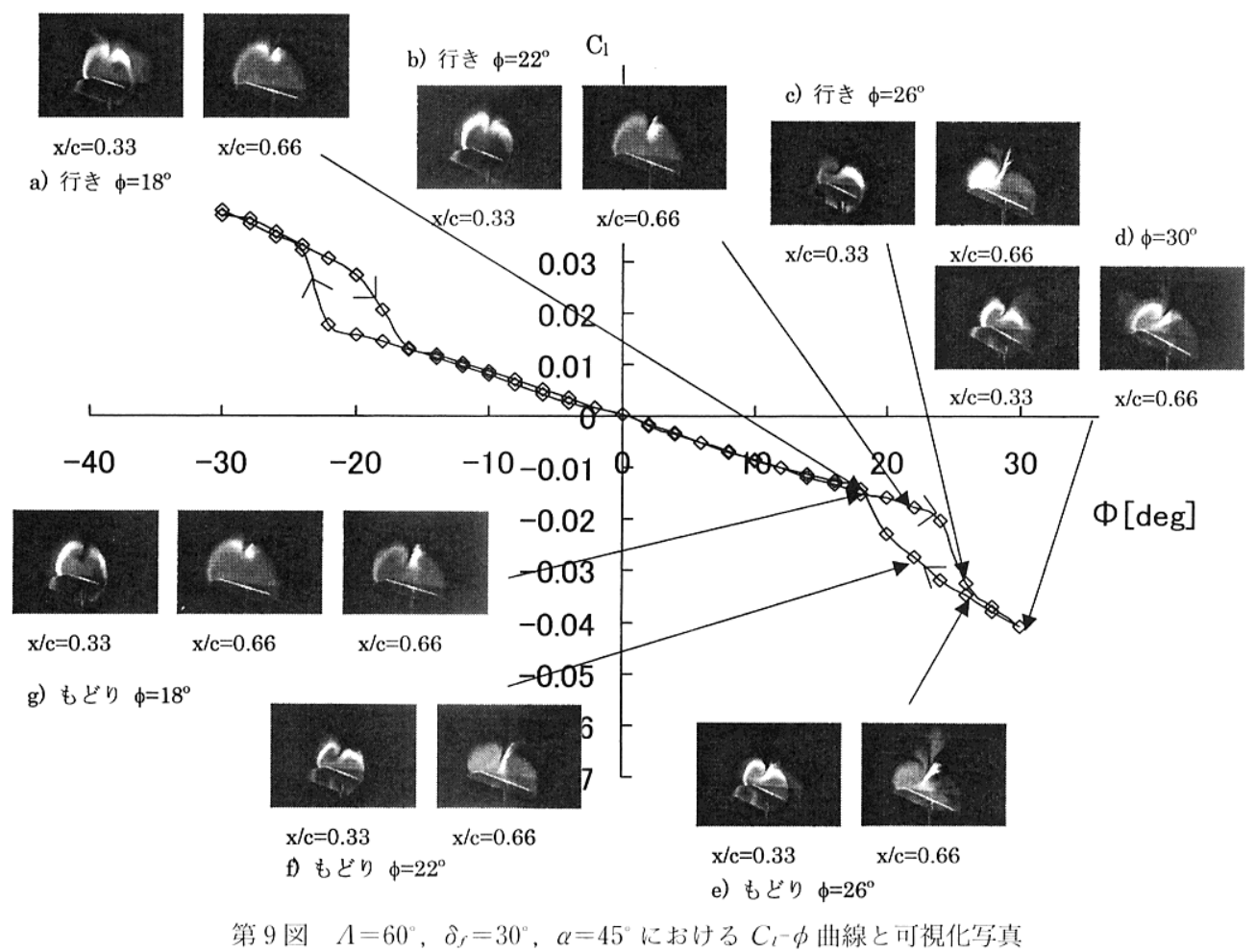

( 298 ) 


\section{えられる。}

3.2 節でも述べたように vortex flap はフラップを下方 に折り曲げるため翼全体の有効迎角を低下させる働きを持 つ.このため, もしフラップを折り曲げていない後退角 $60^{\circ}$ デル夕翼においてヒステリシスが発生するとしたなら

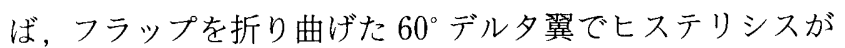
観測された迎角 $\left(\alpha=45^{\circ}\right)$ より小さな迎角でヒステリシス が発生するはずである。しかしながら今回の実験では迎角 45 以下では第 5 図, 第 6 図に示したようにヒステリシス は観測されなかった。すなわち, このヒステリシスの発生 は, ボルテックス・フラップ付きデルタ翼に特有のもので はないかと考えられる。

一方, 後退角 $70^{\circ}, \delta_{f}=30^{\circ}$ の模型を用いて $\alpha=45^{\circ}$ にお いてロール角を第 5 図の場合よりも広い範囲 $(\phi=$ $\left.-37.5^{\circ} \sim 37.5^{\circ}\right)$ で変化させることを試みたが, ヒステリ シスは全く観測されなかった． $\Lambda=70^{\circ}$ 模型で vortex flap を折り曲げてもヒステリシスが発生しなかった原因は $70^{\circ}$ の方が $60^{\circ}$ に比べて剥離渦が強いことに起因しているかも しれないが，この点に関してはまだ検討が不十分である. 更には, 後退角 $60^{\circ}$ という特定のデル夕翼においてなぜ七 ステリシスが観測されたか, 後退角を $60^{\circ}$ より小さくした 場合でも同様な現象が発生するか, また後退角一定のまま でフラップ折り曲げ角度 $\delta_{f}$ を変化させたとしても, 特定 の $\delta_{f}$ でヒステリシスが観測されるのか, 以上挙げた点に ついては今後の研究が必要である. なお, 文献 20)では, ロール角無しで横滑り角を取ると, 平板デル夕翼に働くロ 一リングモーメントにもヒステリシスが発生することが報 告されている。

\section{4. 結論}

後退角 $60^{\circ}$ および $70^{\circ}$ のボルテックス・フラップ付きデ ル夕翼が静的にロール角を有しているときにデル夕翼に働 く法線力とローリングモーメントを測定した．煙を用いた 流れの可視化を行い前縁剥離渦の状態変化も詳細に観察し た。その結果, 以下の結論が得られた。

・後退角 $60^{\circ}$ デル夕翼では vortex flap を折り曲げない場 合と同様に, vortex flapを折り曲げた場合もロール不 安定を生ずる迎角が存在する。これはロールにより, 前 縁剥離渦の breakdown を生ずる翼弦長方向位置が, 左 右の翼で異なるようになるため, 左右の翼に働く空気力 に違いを生じて, 不安定なローリングモーメントを発生 する場合があるためである。

・後退角 $70^{\circ}$ デル夕翼では vortex flap 有り無し共にロー ル不安定が観測されなかった。これは，60デルタ翼に 比べて前縁剥離渦が強いためであると考えられる。

・後退角 $60^{\circ}$, vortex flap 折り曲げ角 $30^{\circ}$, 迎角 $45^{\circ}$ の状 態で法線力，ローリングモーメント共にヒステリシスが 観測された。ロール角が小さいときには左右一対の渦が ほぼ同じ大きさであったものが, あるロール角において 突然風上側（ロールにより下がっている翼側）の渦が風 下側の渦の下に入り込み, 風上側の渦が翼面に近づく現
象が起こるためである．ロール角を逆方向に小さくして いくと，もとの一対の渦の形に觉るが，このときのロー ル角は, 渦の配置が急変したロール角よりも小さいため に，空気力にヒステリシスが観測されたと説明できる。 なお,このヒステリシスはvortex flap無しのデルタ翼 では観測されなかった。

今後は, 後退角やフラップ折り曲げ角などを更に変化さ せて, ボルテックス・フラップ付きデル夕翼のロール特性 について詳細に調べていく必要がある。

本研究を行うに当たり様々な助言をいただいた航空宇宙 技術研究所 郭東潤氏に感謝の意を表します.

\section{参 考 文 献}

1) Hummel, D. and Srinivasan, P.S.: Vortex Breakdown Effects on the Low-Speed Aerodynamic Characteristics of Slender Delta Wing in Symmetrical Flow, J. Royal Aero. Soc., 71 (1967), pp. 319-322.

2) 林 良生：デル夕翼前縁剥離渦と Breakdown, 日本航空宇宙学 会誌, 20 (1972), pp. 623-629.

3) Polhamus, E. C. : Vortex Lift Research : Early Contributions and Some Current Challenges, NASA CP 2416, 1986, pp. 1-30.

4) Rom, J.: High Angle of Attack Aerodynamics, Subsonic, Transonic, and Supersonic Flow, Springer-Verlag, New York, 1992, pp. 8-61 (Chap. 2).

5）吉永 崇, 楯 篤志：デルタ翼のローリング, 第 20 回流体力学講 演会講演集, 1988, pp. 238-241.

6）真保雄一, 传藤淳造：大迎角デルタ翼のロール非定常空気的，日 本航空字宙学会誌, 37 (1989), pp. 476-484.

7) Pamadi, B. N. : Performance, Stability, Dynamics, and Control of Airplanes, AIAA, Virginia, 1998, pp. 673-752 (Chap. 8).

8) Katz, J.: Wing/Vortex Interactions and Wing Rock, Prog. Aero. Sci., 35 (1999), pp. 727-750.

9) Campbell, J. F. and Osborn, R. F.: Leading-Edge Vortex Research: Some Nonplanar Concepts and Current Challenges, NASA CP 2416, 1986, pp. 31-63.

10）李家賢一：航空機に扔ける消とその利用一ボルテックス・フラ ップを例として一, 可視化情報, 13 (1993), pp. 222-227.

11) Ize, C. and Arena, A. S., Jr. : Effects of Asymmetric LeadingEdge Flap Deflection on Delta Wing in Roll, J. Aircraft, 35 (1998), pp. 968-971.

12）郭 東潤，砂田保人，佐藤淳造：ロールするデル夕翼の非定常空 気力に関する研究, 日本航空宇宙学会誌, 45 (1997), pp. 222-230.

13) Rinoie, K., Fujita, T., Iwasaki, A. and Fujieda, H. : Experimental Studies of a 70-Degree Delta Wing with Vortex Flaps, J. Aircraft, 34 (1997), pp. 600-605.

14) Job, C. E., Hsia, A. H., Jenkins, J.E. and Addington, G. A.: Critical States and Flow Structure on a 65-Deg Delta Wing, J. Aircraft, 33 (1996), pp. 347-352.

15）松野 隆, 滝澤勇二, Hamid, H. E., 中村佳朗：ロールするデル夕 翼面上の前縁剩離渦の可視化, 日本航空宇宙学会 30 周年記念講 演会講演集, 1999 , pp. 147-150.

16）松野 隆, 中村佳朗：後退角の小さいデル夕翼のロール自励振 動, 第 31 回流体力学講演会講演集, 1999, pp. 341-344.

17）柳武：ロール振動する大迎角デル夕翼に関する実験（翼半 頂角が $21^{\circ}$ と $7^{\circ}$ の場合), 東京大学工学部航空学科学士論文, 1990.

18）郭 束潤：ロールするデルタ翼の非定常空力特性，日本航空宇宙 学会論文集, 47 (1999), pp. 165-173.

19) Ericsson, L. E. : Effect of Angle of Attack on Roll Character istics of 65-Degree Delta Wing, J. Aircraft, 34 (1997), pp. 573575.

20) Katz, J. and Levin, D. : Static Measurements of Slender Delta Wing Rolling Moment Hysteresis, J. Aircraft, 28 (1991), pp. 282-283. 